\section{Association between Streptococcusmutans levels and severity of caries in Ecuadorian schoolchildren aged 6 to 10 years.}

\author{
Ivonne Adriana Ordóñez ${ }^{1}$, Doris Eliana Calderón ${ }^{1}$, José \\ David Aguilar ${ }^{1}$, Mónica Priscilla Tello ${ }^{1}$, Deniss Paúl \\ Calderón. ${ }^{2}$
}

\begin{abstract}
Dental caries is a multifactorial, infectious and communicable disease, and Streptococcus mutans is the key microorganism related to this pathology. The objective of this study was to evaluate the association between the levels of Streptococcus mutans and caries in schoolchildren. Descriptive, cross-sectional study conducted on 100 schoolchildren aged 6 to 10 years from the Unidad Educativa Checa Cuenca, Ecuador. ICDAS index and odontogram were used to measure the prevalence and severity of caries. For the identification and quantification of Streptococcus mutans, dental plaque samples were used for cultivation and biochemical tests (MicroScan). The results were analyzed statistically using absolute and relative frequencies, for bivariate analysis Chi-squared test and Fisher's Test $(p<0.05)$ were used. 96\% of the schoolchildren presented dental caries, $69 \%$ of them were children aged 8 to 10 years, the prevalence of caries was higher in females reaching $57 \%$. High $(60,000 \mathrm{UFC} / \mathrm{ml})$ and very high $(70,000 \mathrm{UFC} / \mathrm{ml})$ levels of Streptococcus mutans were found on schoolchildren aged 8 to 10 years reaching $22 \%$ and $8 \%$, respectively $(p=0.005)$. Regarding sex, high $(60,000 \mathrm{UFC} / \mathrm{ml})$ as well as very low (0-20,000UFC/ml) levels of Streptococcus mutans appeared without difference by sex $(p=0.355)$. Schoolchildren without caries presented a low count of Streptococcus mutans (0 -20,000 UFC/ml), children with caries presented variable levels of Streptococcus mutans, although higher than $20,000 \mathrm{UFC} / \mathrm{ml}(p<0.001)$. Conclusion: there is a high prevalence of caries in the school population with high levels of Streptococcus mutans.
\end{abstract}

Keywords: Streptococcus mutans, dental caries.

\section{INTRODUCTION}

According to the World Health Organization (WHO), dental caries is a multifactorial disease. Caries begin at the moment when teeth erupt and causes softening of the tooth's hard tissues until the formation of a cavity (World Health Organization, 2012), affecting the life quality of people. The factors that are associated with dental caries are microorganisms, substrate (diet), host (tooth), time (age), deficient oral hygiene, low socioeconomic level, low fluoridation exposure, among others (Cerón-Bastidas, 2015; Velázquez \& Podesta, 2009; Ministerio de Salud Pública, 2016; Peña \& Zavarce, 2016). The main microorganism related to the development of this pathology is Streptococcus mutans (Guerrero et al., 2009; Rivera et al., 2017). The child population is the most vulnerable and important when avoiding early infection by this microorganism (Rivera et al., 2017; Aguilera et al., 2004; 0jeda et al., 2013; Graciano et al., 2014; Sieber, 2012).

Streptococcus mutans is a facultative anaerobic microorganism, the

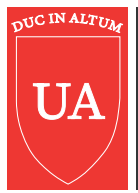

Affiliation: ${ }^{1}$ Universidad Católica de Cuenca sede Azogues, Ecuador. ${ }^{2}$ Universidad de Cuenca, Ecuador.

Corresponding: Doris Eliana Calderón Alemán. Av. 1 de septiembre CuencaEcuador. Phone: +593958938519. Email:

bq_elicalderon@yahoo.com

Receipt:

02/07/2019

Revised:

03/07/2019

Acceptance:

03/21/2019

Online:

$04 / 25 / 2019$
Conflict of interests: None.

Ethics approval: Universidad Católica de Cuenca sede Azogues.

Funding: None.

Authors' contributions: All authors carried out the entire study.

Acknowledgements: None.

doi: $\underline{10.32457 / \text { ijmss.2018.034. }}$

Ordóñez IA, Calderón DE, Aguilar JD, Tello MP, Calderón DP. Association between Streptococcus mutans levels and severity of caries in Ecuadorian schoolchildren aged 6 to 10 years. Int J Med Surg Sci. 2018; 5(4): 132-135. doi: 10.32457/ijmss.2018.034. 
first one to colonize the tooth's surface after its eruption. It receives its name from the ability of changing its shape (Salazar et al., 2008), it metabolizes carbohydrates such as sucrose, glucose and fructose that come from diet, producing acids (lactic, propionic, acetic and formic), which travel through the dental plaque into the enamel, then dissociating and releasing hydrogen ions that cause the loss of calcium and phosphate from the enamel (Guerrero et al., 2009). It can synthesize extracellular polysaccharides (EPS) such as glucans and fructans, which foster selective adherence and accumulation of a high number of cariogenic streptococci in the teeth (Velásquez et al., 2017). Some studies have shown that mothers have children with the same levels of microorganisms (Cerón-Bastidas, 2015; Pérez et al., 2007).

There are automated identification methods on the market (MicroScan) that surpass conventional methods, since they are easy to use (Ojeda et al., 2013; Bou et al., 2011). On the other hand, the ICDAS index is a method that is used for the early identification of dental caries (Cerón-Bastidas, 2015; Peña \& Zavarce, 2016; Ramón et al., 2016), differentiating accurately the manifestations of the caries process in the hard tissues (Gamboa, 2014). Associations between caries and Streptococcus mutans count have been found on different studies (Guerrero et al., 2009; Rivera et al., 2017; Aguilera et al., 2004; Ojeda et al., 2013; Graciano et al., 2014; Sieber, 2012). However, it has been observed that this disease can occur in absence of this microorganism and that individuals with higher counts do not necessarily develop carious lesions.

The aim of this study was to evaluate the association between the levels of Streptococcus mutans and caries in schoolchildren. Descriptive, cross-sectional study performed on 100 schoolchildren aged 6 to 10 years from the Unidad Educativa Checa Cuenca, Ecuador.

\section{MATERIALS AND METHODS}

A cross-sectional study was conducted on a target population of 143 schoolchildren of the Unidad Educativa Checa from the city of Cuenca - Ecuador. A sample of 100 schoolchildren was estimated, adjusted to expected dropout.

The following inclusion criteria were considered for the formalization of the population. Students enrolled in the Unidad Educativa Checa, ranging from 6-10 years of age until January 31st of 2018.

Data were obtained through epidemiological records and laboratory exams, the patients' parents were informed in writing of the objectives and methodology.

For the identification of caries, the ICDAS clinical forms of the Universidad Católica de Cuenca and odontogram were used, and the identification of microorganisms was achieved via a sample of the bacterial plaque. Data collection was performed as follows.

ICDAS clinical form was completed after clinical examination of all dental pieces, the corresponding code was registered.

Code 0: healthy teeth.

Code 1: white/brown stain on dry enamel.

Code 2: white/brown stain on humid enamel.

Code 3: microcavity in dry enamel $<0.5 \mathrm{~mm}$ without visible dentine.

Code 4: dark dentine shade seen through humid enamel with or without microcavity.

Code 5: dentine exposure in cavity $>0,5 \mathrm{~mm}$ up to half of the dry dental surface.

Code 6: dentine exposure in cavity greater than half of the dental surface.

For the identification and quantification of Streptococcus mutans:

Sampling of bacterial plaque of the gingival margin using swab, then placed on Stuart transport medium for submission to laboratory.

Seeding on Petri dish with sheep blood agar.

Incubation in anaerobiosis jar for two days at $37^{\circ} \mathrm{C}$.

Quantification of colonies with surface method (valuation: colony forming units per milliliter (CFU/ml)).

Application of catalase test (reaction with hydrogen peroxide), (negative for streptococci).

Microscope observation after Gram staining for initial identification of Gram-positive cocci.

For inoculum preparation (turbidity standard 
technique) 3 to 4 morphologically equal colonies were collected with inoculating loop. $3 \mathrm{ml}$ of water were added and the suspension was shaken for $2-3$ seconds. $0.1 \mathrm{ml}$ of the suspension was extracted with automatic pipette in $25 \mathrm{ml}$ of pluronic water for inoculum.

Biochemical tests were performed through incubation in MicroScan system (Beckman Coulter, USA). Alternatively, an incubator might be used, which ensures a uniform thermal distribution for 16 to 20 hours at $35^{\circ} \mathrm{C}$.

Interpretation of biochemical tests in MicroScan (Labpro, Beckman Coulter, USA).

The obtained results were analyzed statistically using absolute and relative frequencies. For bivariate analysis Chi-squared test and Fisher's exact test were used $(p<0.05)$.

\section{RESULTS}

$96 \%$ of the schoolchildren presented dental caries, $69 \%$ of them corresponded to children aged 8 to 10 years $(p=0.203)$, the prevalence of caries was higher in females reaching $57 \%$.

The high $(60,000 U \mathrm{FC} / \mathrm{ml})$ and very high (70,000UFC/ml) Streptococcus mutans levels were found on schoolchildren aged 8 to 10 years reaching $22 \%$ and $8 \%$, respectively, the lower counts $(0-20,000 U F C / m l)$ were found on schoolchildren aged 6 to 7 years reaching $19 \%$ $(p=0.005)$.

Regarding sex, high $(60,000 U \mathrm{FC} / \mathrm{ml})$ as well as very low $(0-20,000 U \mathrm{FC} / \mathrm{ml})$ Streptococcus mutans levels were found on male and female schoolchildren $(p=0.355)$. Schoolchildren without caries showed a very low count of Streptococcus mutans $(0-20,000 U F C / m I)$, schoolchildren with caries presented variable levels of Streptococcus mutans, although higher than $20,000 \mathrm{UFC} / \mathrm{ml}(p=0.000)$.

\section{DISCUSSION}

Streptococcus mutans is a key microorganism related to high caries indexes and, thus, it is considered one of the main risk factors for this disease. In this study, $96 \%$ of schoolchildren presented dental caries, Aguilera et al. (2004) performed a similar study on children aged 6-13 years, however, they used saliva and not dental plaque as sample and found that the prevalence of dental caries was $56 \%$, which does not agree with the results of this study, maybe because they studied older children. In that study it was established that children with caries had higher levels of Streptococcus mutans.

Another research with similar results corresponds to Sieber (2012), who managed to isolate Streptococcus mutans in $94.2 \%$ of the samples. One difference with that study was the use of the bulb method for identification. Graciano et.al (2014) showed similar results regarding levels of Streptococcus mutans and prevalence of caries in a population of schoolchildren and found out that $56 \%$ of the population that presented caries showed Streptococcus mutans counts higher than $105 \mathrm{mil}$ UFC/ml found by Rivera et al. (2017).

Salazar et al. (2008) conducted a study on Streptococcus mutans count in saliva through microbiological method and managed to isolate $88.2 \%$ of the samples, according to the degree of cariogenic risk. A Streptococcus mutans prevalence of $100 \%$ was observed in the high risk group, which agrees with the results of this study.

Velásquez et al. (2017) performed a study on Streptococcus mutans count in saliva on children aged 6 to 12 years and managed to isolate the Streptococcus mutans levels higher than $20,000 \mathrm{UFC} / \mathrm{ml}$, which agrees with this study's results, since children with caries presented variable levels of Streptococcus mutans, although higher than 20,000 UFC $/ \mathrm{ml}$.

\section{CONCLUSION}

A high prevalence of dental caries was observed in the studied population, revealing, at the same time, a relationship between the high number of $\mathrm{UFC} / \mathrm{ml}$ of Streptococcus mutans and the presence of caries.

\section{REFERENCES}

Aguilera LA, Sánchez CG, Neri CA, Aceves MC. Streptococcus mutans en saliva y su relación con la caries dental en una población infantil de Tacoaleche Guadalupe, Zacatecas. Rev ADM. 2009; 65(6):48-56.

Cerón-Bastidas XA. El sistema ICDAS como método complementario para el diagnóstico de caries dental. CES Odontol. 2015; 28(2):100-109. 
Bou G, Fernández-OImos A, García C, Sáez-Nieto JA, Valdezate S. Métodos de identificación bacteriana en el laboratorio de microbiología. Enferm Infecc Microbiol Clin. 2011; 29(8):6018.

Gamboa F. Identificación y caracterización microbiológica, fenotípica y genotípica del Streptococcus mutans: experiencias de investigación. Univ Odontol. 2014; 33(71):65-73.

Guerrero VM, Godinez AG, Melchor CG, Rodríguez ME, Luengas QE. Epidemiología de caries dental y factores de riesgo asociados a la dentición primaria en preescolares. Rev ADM. 2009; 65(3):10-20.

Graciano ME, Correa YA, Martínez CM, Burgos A, Ceballos JI, Sánchez LF. Streptococcus mutans y caries dental en América Latina. Revisión sistemática de la literatura. Rev Nac Odontol. 2014; 8(14): 65-75.

Ministerio de Salud Pública. Protocolos Odontológicos. Salud Bucal. Primera ed. Dirección Nacional de Normalización. Quito: MINSA; 2016.

Ojeda JC, Oviedo E, Salas LA. Streptococcus Mutans and dental caries. CES Odontol. 2013; 26(1): 44-55.

Peña E, Zavarce E. Prevalencia de caries dental utilizando el sistema internacional ICDAS en pacientes que acuden a consulta pediátrica en dos instituciones de la Ciudad de Valencia, Estado Carabobo, Venezuela. Acta Odontol Venez. 2016; 54(2).

Pérez JA, Duque J, Hidalgo I. Asociación del Estreptococos mutans y lactobacilos con la caries dental en niños. Rev Cubana Estomatol. 2007;44(4):1-13.

Ramón R, Castañeda M, Corona MH, Estrada GA, Quinzán AM. Factores de riesgo de caries dental en escolares de 5 a 11 años. MEDISAN. 2016; 20(5): 648-654.

Rivera AM, Artigas AA, Buitrago E, Viguera Y. Prevalencia y factores de riesgo de caries dental en pacientes del municipio Urbano Noris. ccm. 2017; 21(1):139-154.

Salazar LA, Vásquez C, Almuna A, Oporto G, Santana R, Herrera CL, Sanhueza A. Detección Molecular de Estreptococos Cariogénicos en Saliva. Int J Morphol. 2008; 26(4):951-958.

Sieber C. Recuento de Streptococcus mutans en muestras de biofilm sobre dientes restaurados con resina compuesta oclusal versus dientes sanos mediante el método de cubeta. [Thesis]. Chile: Universidad de Chile - Facultad de Odontología; 2012.

Velázquez C, Salinas I, Godoy P, Muñoz H, Barría RM. Recuento en saliva de Streptococcus mutans en niños de 6 a 12 años con y sin tinciones cromógenas. Av Odontoestomatol. 2017; 33(2):77-83.

Velazquez 0, Podesta M. Adquisición temprana de Streptococcus mutans y caries dental. Rev Dent Tribune Hispanic Latin Am. 2009:1(1): 22-26.

World Health Organization. Oral health surveys: basic methods - 5th edition. Available at: http://www.who.int/ mediacentre/factsheets/fs $318 / \mathrm{es} /$.

Ordóñez IA, Calderón DE, Aguilar JD, Tello MP, Calderón DP. Association between Streptococcus mutans levels and severity of caries in Ecuadorian schoolchildren aged 6 to 10 years. Int J Med Surg Sci. 2018; 5(4): 132-135. doi: 10.32457/ijmss.2018.034. 